\section{Cytotoxicity and cytokine production by calcium silicate- based materials on periodontal ligament stem cells}

\author{
Marlus da Silva Pedrosa (D1, Tomaz Alves (D) 1, Fernando Neves \\ Nogueira (D)1, Marinella Holzhausen (D2), Carla Renata Sipert (D)3
}

\begin{abstract}
This study investigated the effect of three commercial calcium silicate-based materials (CSBM) on cytotoxicity and pro-and anti-inflammatory cytokines production in cultured human periodontal ligament stem cells (hPDLSCs). Culture of hPDLSCs was established and characterized. Extracts of Bio-C Sealer (Angelus, Londrina, PR, Brazil), MTA Fillapex (Angelus, Londrina, PR, Brazil) and PBS Cimmo HP (Cimmo Soluções em Saúde, Pouso Alegre, MG, Brazil) were prepared by placing cement specimens $(5 \times 3 \mathrm{~mm})$ in culture medium. Then, the extracts were serially two-fold diluted $(1,1: 2,1: 4,1: 8$, 1:16) and inserted into the cell-seeded wells for 24,48 and $72 \mathrm{~h}$ for MTT assays. TNF- $\alpha$ and IL-10 cytokines were quantified by ELISA at $24 \mathrm{~h}$-cell supernatants. Data were analyzed by ANOVA and Tukey's test $(\alpha=0.05)$. All CSBM exhibited some cytotoxicity that varied according to extract concentration and time of evaluation. MTA Fillapex presented the highest cytotoxic effects with significant reduction of metabolic activity/cell viability when compared to Bio-C Sealer and Cimmo HP ${ }^{\circledR}$. TNF- $\alpha$ was significantly upregulated by the three tested cements $(p<0.05)$ while only MTA Fillapex significantly upregulated IL-10 in comparison to control. Taken collectively, the results showed that PBS Cimmo $\mathrm{HP}^{\circledR}$, Bio-C Sealer and MTA Fillapex present mild and transient cytotoxicity and slightly induced TNF- $\alpha$ production. MTA Fillapex upregulated IL-10 release by hPDLSCs.
\end{abstract}

1 University of São Paulo - USP, School of Dentistry, Department of Biomaterials and Oral Biology, São Paulo, SP, Brazil.

2 University of São Paulo - USP, School of Dentistry, Discipline of Periodontology, Department of Stomatology, São Paulo, SP, Brazil.

3 University of São Paulo - USP, School of Dentistry, University of São Paulo, São Paulo, SP, Brazil.

Correspondence: Prof. Carla Sipert Departamento de Dentística, Faculdade de Odontologia, Universidade de São Paulo (USP). Av. Prof. Lineu Prestes 2227, 05508-900, São Paulo, SP, Brasil.

E-mail address: sipert@usp.br

Key Words: Cytotoxicity, dental cements, cytokines, periodontal ligament.

\title{
Introduction
}

Calcium silicate-based materials (CSBM) have been introduced over the last years and gained popularity in endodontics due to their physicochemical and biological properties $(1,2)$. These materials can favor the inducement of periapical healing and hard tissue formation despite being used in many clinical applications such as pulp capping, root-end filling, perforation repair, and apical plugs $(1,2)$.

Investigating the effect of CSBM on periapical tissues is considered essential since these materials should not impair the healing process or lead to severe inflammatory reaction $(3,4)$. However, CSBM may promote cytotoxicity and induce an inflammatory reaction (5-7). Cytotoxicity tests allow the understanding of the biological effects caused by material or its extract in cell culture. Human periodontal ligament stem cells (hPDLSCs) have been seen as a promising cell model for the evaluation of the cytotoxicity of endodontic sealers $(8,9)$.

Studies have led to the development of new $\operatorname{CSBM}(2,10)$. Among these materials, Bio-C sealer ${ }^{\circledR}$ (Angelus, Londrina, PR, Brazil) and Cimmo HP ${ }^{\circledR}$ (Cimmo Soluções em Saúde, Pouso Alegre, MG, Brazil) were recently introduced $(2,10)$. However, to date, the literature evaluating how these new materials could affect the cell viability and inflammatory response are scarce.

Therefore, this study aimed to investigate the effect of three CSBM (Bio-C Sealer, MTA Fillapex and PBS Cimmo HP${ }^{\circledR}$ ) on the cytotoxicity and pro- and anti-inflammatory cytokines production by cultured hPDLSCs. The null hypotheses tested were: (i) there would be no difference in cytotoxicity between the CSBM and the negative control group (ii) the CSBM would not interfere in the production of pro- and anti-inflammatory cytokines by the hPDLSCs. 


\section{Material and Methods}

Primary culture of hPDLSCs

This in vitro experimental protocol was approved by the Ethics Committee of the School of Dentistry of the University of São Paulo (Protocol\# 3.895.056). The hPDLSCs were obtained from the cell biobank of the School of Dentistry of the University of São Paulo. Cells were thawed in Minimum Essential Medium $\alpha(\alpha-M E M)$ (Invitrogen) with 10\% fetal bovine serum (FBS) (Gibco) and antibiotics $(100 \mu \mathrm{g} / \mathrm{mL}$ penicillin, $100 \mu \mathrm{g} / \mathrm{mL}$ streptomycin, $0.5 \mathrm{mg} / \mathrm{mL}$ amphotericin B - Invitrogen) at standard culture conditions $\left(37^{\circ} \mathrm{C}, 100 \%\right.$ humidity, $5 \% \mathrm{CO}_{2}$ and $95 \%$ air). hPDLSCs from passage four were used for cytotoxicity and quantitative assays. hPDLSCs were seeded at $2 \times 10^{4}$ cells per well and grown in $\alpha$-mem (11).

\section{Phenotypic characterization of PDLSCs}

hPDLSCs characterization was performed by using immunostaining and flow cytometry. Cells were seeded at $5 \times 10^{5}$ cells/well and incubated in 5\% FBS/PBS $1 \times$ at $4{ }^{\circ} \mathrm{C}$ protected from light for 1 hour with the following monoclonal antibodies: OCT4-FITC, SOX2-FITC, STR0-1-FITC (Abcam), CD90-FITC (eBioscience), CD34-FITC (Biolegend), CD31-PE, CD-44-PE (eBioscience, ) and CD146-PE (Biolegend) for $30 \mathrm{~min}$ at $4^{\circ} \mathrm{C}$. Unstained control was used to set gates. A total of 10-50,000 events were recorded and data analyzed by FlowJo software (Becton) (11).

\section{Preparation of conditioned medium}

The composition of the tested materials is described in table 1 . The materials were manipulated according to the manufacturers' instructions and were inserted into a round metal appliance designed for the production of discs $(5 \times 3 \mathrm{~mm}$ ). Materials were allowed to set for $24 \mathrm{~h}$ in a humid atmosphere and aseptic conditions. After setting, each specimen was immersed into $1 \mathrm{~mL}$ of $\alpha$-MEM and incubated for $72 \mathrm{~h}$. The extracts were filtered by $0.22-\mu \mathrm{m}$ pore size membranes (Millipore) $(4,12)$.

\begin{tabular}{|c|c|c|c|}
\hline Materials & Manufacturer & Composition & Proportion \\
\hline Bio-C Sealer ${ }^{\circledR}$ & Angelus, Londrina, PR, Brazil & $\begin{array}{l}\text { Calcium silicates, calcium aluminate, } \\
\text { calcium oxide, zirconium oxide, iron } \\
\text { oxide, silicon dioxide, dispersing } \\
\text { agent }\end{array}$ & Ready to use \\
\hline MTA Fillapex ${ }^{\circledR}$ & Angelus, Londrina, PR, Brazil & $\begin{array}{l}\text { Paste A: salicylate resin, bismuth } \\
\text { trioxide, and fumed silica } \\
\text { Paste B: fumed silica, titanium } \\
\text { dioxide, mineral trioxide aggregate, } \\
\text { and base resin }\end{array}$ & $1 \mathrm{~g}: 1 \mathrm{~g}$ (paste / paste) \\
\hline Cimmo $\mathrm{HP}^{\circledR}$ & $\begin{array}{l}\text { Cimmo Soluções em Saúde, } \\
\text { Pouso Alegre, MG, Brazil }\end{array}$ & $\begin{array}{l}\text { Calcium oxide, calcium carbonate, } \\
\text { magnesium oxide, dicalcium silicate, } \\
\text { aluminum oxide, sodium oxide, } \\
\text { potassium oxide and pozzolan with } \\
\text { additives }\end{array}$ & $\begin{array}{l}0.2 \mathrm{~g} \text { powder / } 60 \mathrm{uL} \\
\text { liquid (distilled water) }\end{array}$ \\
\hline
\end{tabular}

\section{Cell stimulation with materials extracts}

The extracts were serially two-fold diluted $(1,1: 2,1: 4,1: 8,1: 16)$ in $\alpha$-MEM. hPDLSCs were counted and seeded at $2 \times 10^{4}$ cells/well in 96-well plates. After $24 \mathrm{~h}$, the cells were incubated with $100 \mu \mathrm{L}$ of the extracts of CSBM. In the negative control group (NC), $100 \mu \mathrm{L}$ of $\alpha$-MEM were applied to the cells. The experiments were performed in triplicate and at different time intervals, according to the ISO 1099312:2012 (E) recommendations (12). 


\section{Cytotoxicity assay}

After 24, 48 and $72 \mathrm{~h}$ of stimulation with the CSBM extracts, the cell supernatant was replaced by $20 \mu \mathrm{L}$ of a solution of $5 \mathrm{mg} / \mathrm{mL}$ of MT (Sigma-Aldrich) in PBS, followed by $180 \mu \mathrm{L}$ of $10 \% \mathrm{FBS} \alpha-\mathrm{MEM}$. Cells were incubated for $4 \mathrm{~h}$ and MT solution was replaced by $100 \mu \mathrm{L}$ of dimethyl sulfoxide (Synth, Diadema, SP, Brazil). Optical density was determined using a plate reader (Synergy HT, Biotek, Instruments, Inc. Winooski, VT, USA) at $570 \mathrm{~nm}$. The numerical data obtained were converted into percent of the negative control group.

\section{Quantification of cytokines}

hPDLSCs were culture $\left(2 \times 10^{4}\right)$ and stimulated with the CSBS ( $1: 8$ dilution) for $24 \mathrm{~h}$. Quantification of TNF- $\alpha$ and II-10 was performed in the cell culture supernatants by commercially available Duo-Set Enzyme-linked immunosorbent assay (ELISA) kits from R \& D Systems.

\section{Statistical analysis}

Normal data distribution was verified through the Shapiro-Wilk normality test and data were analyzed by analysis of variance (ANOVA) followed by Tukey's test $(\alpha=0.05)$. All statistical analyses were performed using GraphPad Prism 7.00 (GraphPad Software, Inc., CA, US).

\section{Results}

Phenotypic characterization

The results for the characterization of the hPDLSCs by flow cytometry (Figure 1) revealed high expression of CD-44 (100\%), CD-90 (96.9\%), and CD-146 (96.3\%) and low expression of CD-31 (7.65\%), CD-34 (6.55\%), OCT-4 (12.6\%) and SOX-2 (11.7\%). STRO-1 was 54.9\%.
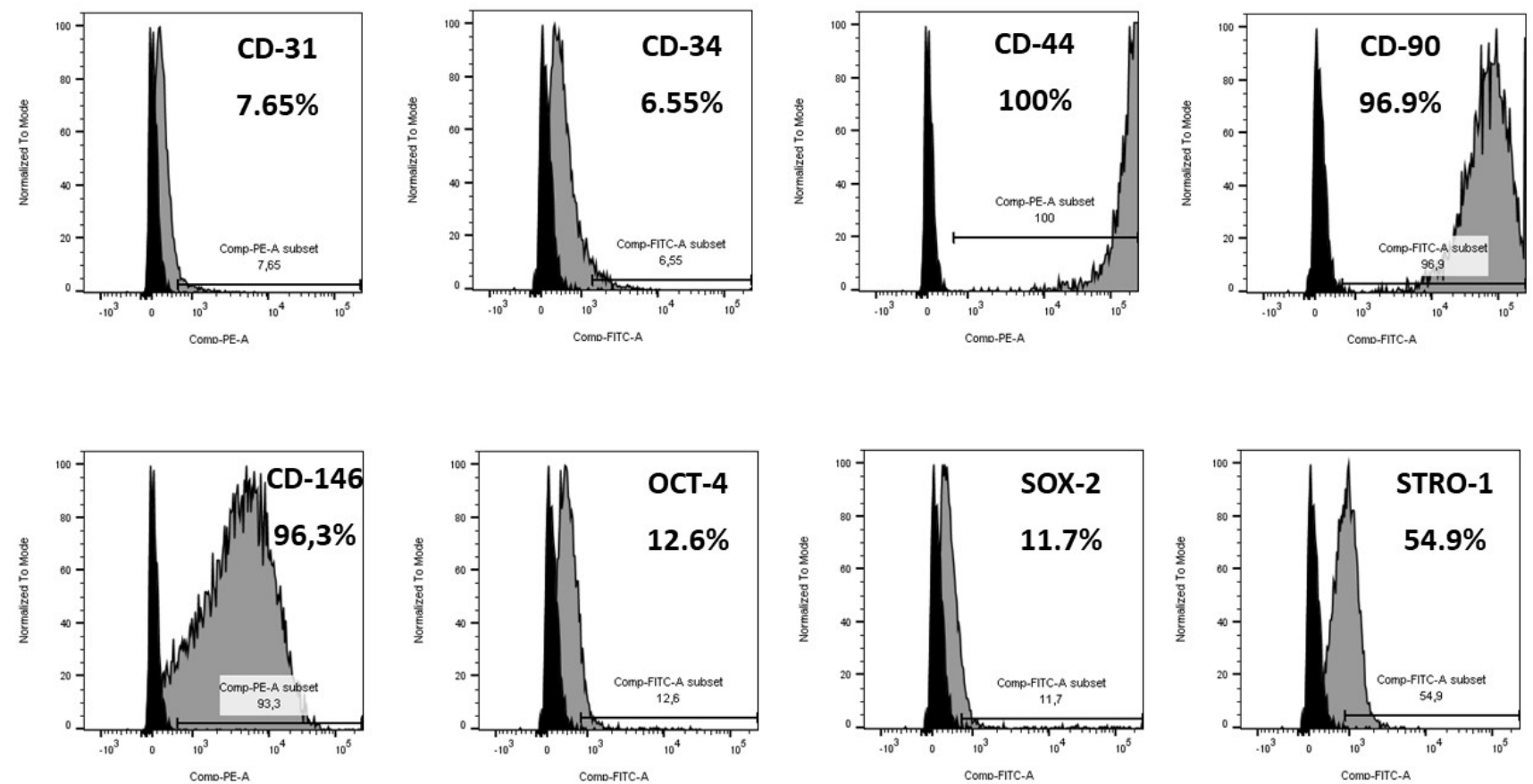

Figure 1. Characteristics of the human periodontal ligament cells (hPDLCs). Surface markers were detected by flow cytometry. hPDLCs stained with surface markers are shown as brown curves, and control hPDLCs with no staining are shown as black curves.

\section{Cell viability}

After $24 \mathrm{~h}$, Bio-C Sealer at 1:8 dilution presented a cytotoxic effect on the hPDLSCs (Figure 2A) ( $p$ $<0.05)$. These was differences were observed for any concentration of Cimmo HP ${ }^{\circledR}$ and MTA Fillapex compared to control (Figures 2D and $2 \mathrm{G})(\mathrm{p}>0.05)$.

At $48 \mathrm{~h}$, no differences regarding the cell viability rate were observed in any concentration of BioC Sealer compared to control group (Figure $2 B)(p>0.05)$. For PBS Cimmo HP ${ }^{\circledR}$ at $48 \mathrm{~h}$, the undiluted extract was found to be cytotoxic. On the other hand, improved absorbance is noticed at 1:8 dilution 
(Figure 2E) ( $p<0.05)$. After a $48 \mathrm{~h}$ period, MTA fillapex 1 and 1:2 dilution presented a cytotoxic effect on the hPDLSCs (Figure $2 \mathrm{H})(\mathrm{p}<0.05)$. The 1:16 dilution of the Bio-C Sealer, however, presented significantly higher values in absorbance compared to $\mathrm{NC}$ and the other concentrations (Figure $2 \mathrm{H})(\mathrm{p}<$ 0.05).

The cell viability analyzed at $72 \mathrm{~h}$ showed that undiluted Bio-C Sealer (Figure $2 \mathrm{C}$ ) and Cimmo HP (Figure 2F), and MTA Fillapex at 1, 1:2 and 1:4 dilutions (Figure 2l) presented a cytotoxic effect on the hPDLSCs. Improved absorbance was detected at 1:16 dilution of Bio-C sealer (Figure $2 C)(p<0.05)$. 

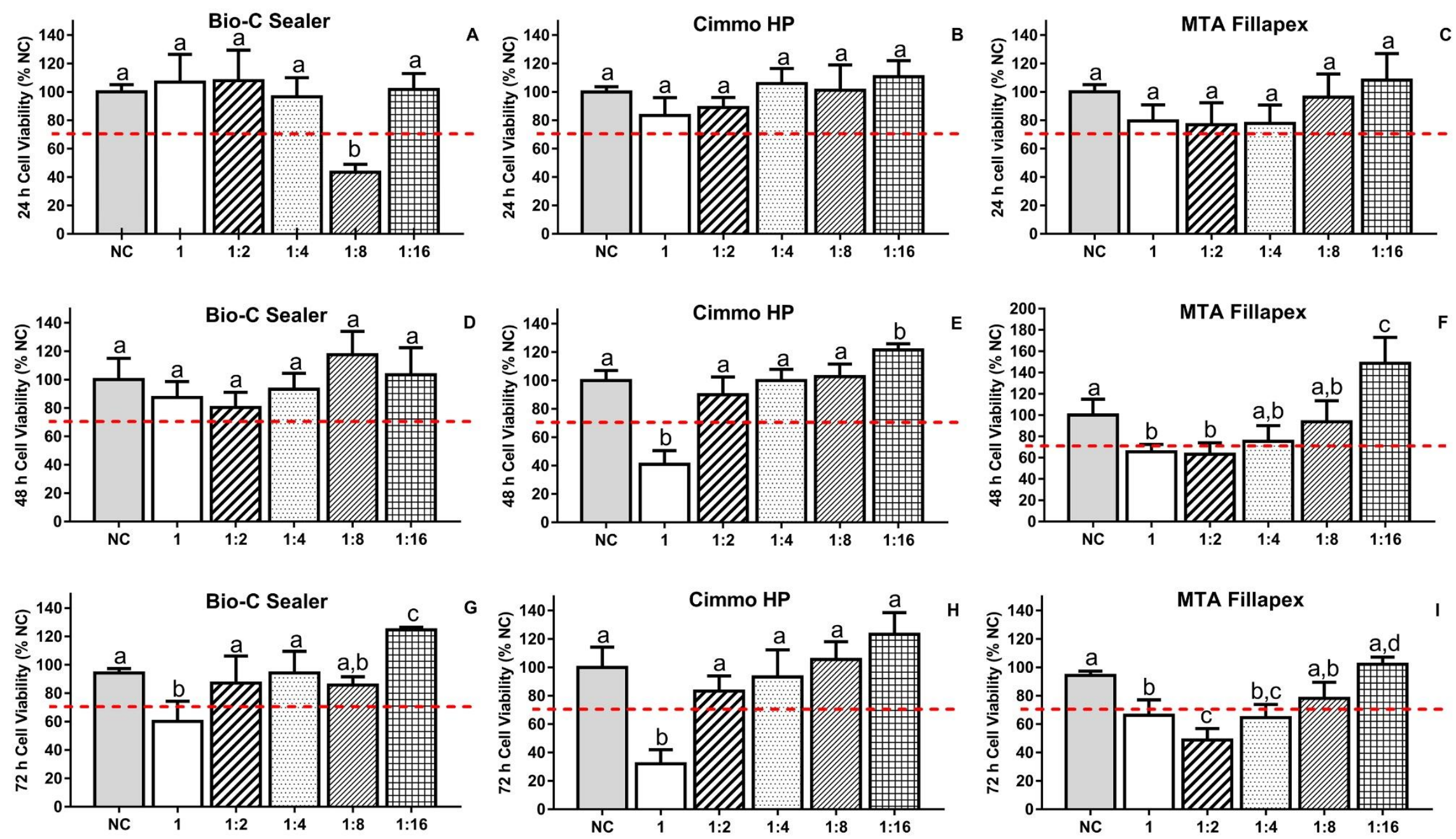

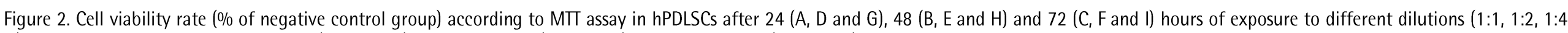

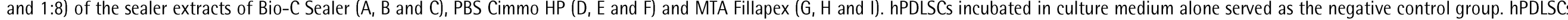

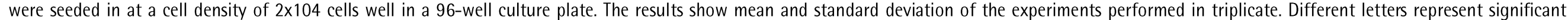
differences between groups in each dilution extract. Analysis of variance followed by Tukey post hoc test $(p<0.05)$. 


\section{Cytokine production}

Figure 3 shows TNF- $\alpha$ and IL-10 concentration according to ELISA assay in hPDLSCs after $24 \mathrm{~h}$ of exposure to the 1:8 dilution of Bio-C Sealer, Cimmo HP ${ }^{\circledR}$ and MTA Fillapex. The concentration of TNF- $\alpha$ was significantly higher for Bio-C Sealer, Cimmo HP ${ }^{\circledR}$ and MTA Fillapex compared to the control group $(p<0.05)$. No differences were observed in TNF- $\alpha$ concentration between the CSBM ( $p>0.05)$. Contrastingly, for IL-10, only MTA Fillapex presented significantly higher values compared to NC, Bio-C Sealer and Cimmo HP ${ }^{\circledR}(p<0.05)$. In addition, no differences were observed in IL-10 values between control, Bio-C Sealer and Cimmo HP® ${ }^{\circledR}(p>0.05)$.

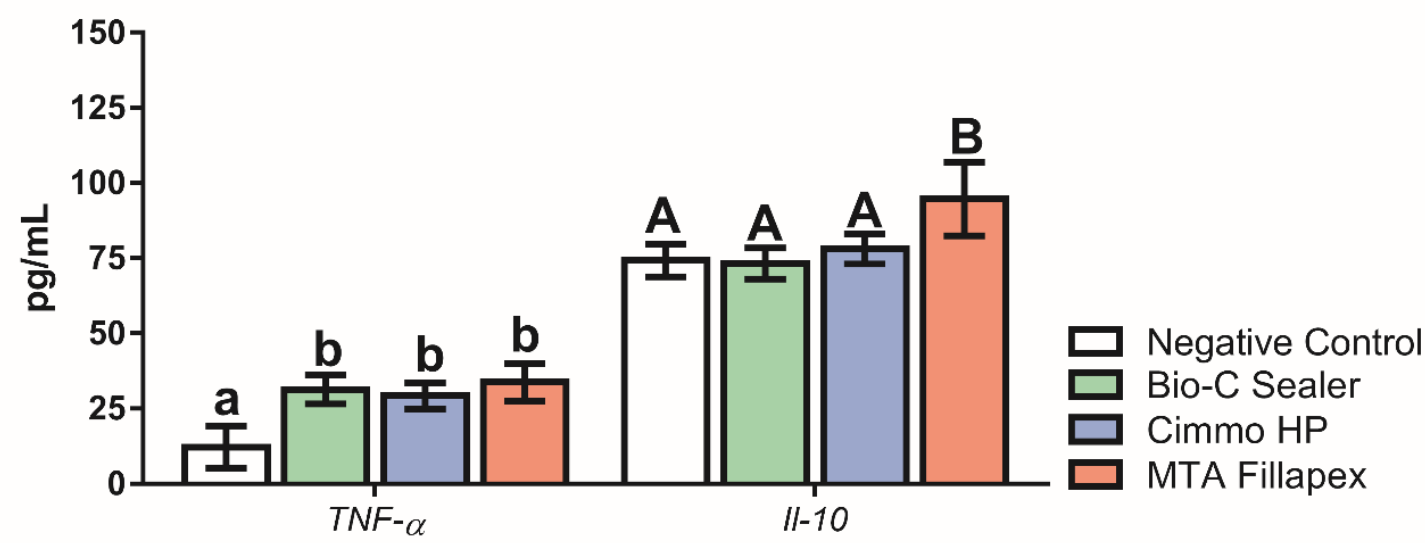

Figure 3. TNF- $\alpha$ and IL-10 concentration according to ELISA assay in hPDLSCs after 24 hours of exposure to 1:8 dilution of Bio-C Sealer,PBS Cimmo HP and MTA Fillapex. hPDLSCs incubated in culture medium alone served as the negative control group. hPDLSCs were seeded in at a cell density of $2 \times 10^{4}$ cells well in a 96-well culture plate. The results show mean and standard deviation of the experiments performed in triplicate. Different letters represent significant differences between groups. Analysis of variance followed by Tukey post hoc test $(p<0.05)$.

\section{Discussion}

In general, root canal sealers present mild to severe toxic effects depending on their composition and handling (13). According to the ISO 10993-5:1999 (E) recommendations, biomaterials that promote reduction in cell viability by more than $30 \%$ are considered cytotoxic (14). Based on the obtained results, the two null hypothesis were rejected as the CSBS showed different profiles of cytotoxicity and production of inflammatory cytokines in the cultured hPDLSCs.

hPDLSCs are a heterogeneous cell population with a higher proliferation and differentiation ability (15). In this study, the phenotypic characterization of the cells showed percentages of positive and negative markers in agreement with previous studies to be considered a hPDLSC lineage $(15,16)$.

Several methods have been proposed for evaluating the biocompatibility of endodontic materials (17). The MTT assay, used in this study, measures metabolic activity (17). It is considered a simple, reliable, accessible method $(17)$ to assess the cytotoxicity of endodontic sealers $(3,17)$. It is worth to mention that $\mathrm{MT}$ assay does not differentiate cell cycle or metabolism alterations, anti-proliferative effects, apoptosis or necrosis (17). As the cements release soluble components that may be diluted by tissue fluids, we worked with the sealer extracts in order to evaluate the effect of a possible dose-response dilution that possibly occurs in vivo (4).

Among the tested materials in this study, the MTA Fillapex showed higher cytotoxic levels over the hPDLSCs in comparison to Bio-C Sealer and Cimmo HP ${ }^{\circledR}$ at $48 \mathrm{~h}$ and $72 \mathrm{~h}$. This has also been observed in other studies in which MTA Fillapex was compared to other CSBM $(4,5,7)$. The higher toxicity of MTA Fillapex may be attributed to the presence of resinous components, which may reduce cell viability (7). In addition, the cytotoxicity of MTA Fillapex is dose and time-dependent, which is in agreement with previous studies $(4,7)$.

The Bio-C Sealer is a recently developed calcium-silicate-based and ready-to-use material (6) for permanent filling and sealing during root canal treatment (13). It presents shorter setting time and higher solubility but with lower dimensional change compared to other sealers (18). It is composed of calcium silicates, calcium aluminate, calcium oxide, zirconium oxide, iron oxide, silicon dioxide, and dispersing agents $(2,6,13)$. According to the manufacturer, its bioactivity is attributed to the release of calcium ions that stimulate the formation of mineralized tissue (13). 
Bio-C Sealer at 1:8 dilution affected the cell viability in the first $24 \mathrm{~h}$. At $48 \mathrm{~h}$, the material did not show any cytotoxic effect over the hPDLSCs. A dose-response dilution was observed over $72 \mathrm{~h}$ and interestingly, the Bio-C Sealer at 1:16 dilution lead to the highest metabolic activity/cell proliferation according to the MTT assay. Similar results were found by a recent study (13), in which Bio-C Sealer did not affect cell viability in any extract in the first $24 \mathrm{~h}$ and was significantly less cytotoxic than AH Plus. Also, MTT assays in V-79 cell lines showed that Bio-C Sealer had higher cell viability rates at all the dilutions tested (6).

The Cimmo HP ${ }^{\circledR}$ did not show any cytotoxic activity over the hPDLSCs at $24 \mathrm{~h}$. Interestingly, Cimmo $\mathrm{HP}^{\circledR}$ at 1:16 dilution led to higher metabolic activity/cell proliferation compared to control. Similarly to Bio-C Sealer at $72 \mathrm{~h}$ and MTA fillapex at 48 and $72 \mathrm{~h}$, the Cimmo HP ${ }^{\circledR}$ at $72 \mathrm{~h}$ the cytotoxicity obeyed a dose-response dilution. The Cimmo $\mathrm{HP}^{\circledR}$ was developed by the improvement of the characteristics of Portland cement $(19,20)$. This cement presents basic requirements such as hermetic sealing, biocompatibility and bioactivity $(19,20)$. However, to the best of our knowledge, the literature lacks studies regarding the cytotoxicity effect of this material on dental stem cells.

The immune response caused by calcium silicate-based sealers is a key process in tissue healing $(5,21,22)$. Cytokines are molecular messengers that promote inflammatory and wound healing events (23). Thus, the evaluation of cytokine production is also a key-point to better understand the behavior of these materials $(5,21,22)$. Different CSBM were found to exhibit different pro-inflammatory and antiinflammatory cytokine production on PDLSCs $(5,8,9,21,22,24)$. TNF- $\alpha$ is a critical pro-inflammatory cytokine which main function is to regulate the migration and activation of neutrophils and macrophages to ultimately kill microorganisms (23). On the other hand, IL-10 is an anti-inflammatory cytokine associated with collagen synthesis, cell proliferation and inhibition of osteoclastic activation (23). Thus, the quantification of TNF- $\alpha$ and IL-10 was performed to investigate the effect of sealers on the inflammatory response and cell function.

Pro-inflammatory cytokines, as TNF- $\alpha$, are known to be involved in the initiation of the inflammatory process and may contribute to a sequence of healing events (23). In this study, the release of TNF- $\alpha$ by the hPDLSCs in the culture medium was stimulated by all the tested sealers suggesting their inflammatory potential when in contact with living cells. Interestingly, reduction of the expression of TNF- $\alpha$ was found in C3T3-E1 cells stimulated with MTA Fillapex extract for two days (25). Besides, this sealer was shown to induce lower expression of TNF- $\alpha$ in immortalized hPDLSCs for 7 and 14 days (24). In our study, the hPDLSCs were stimulated for $24 \mathrm{~h}$, thus the differences found may be attributed to the different cells and periods of evaluation. These findings suggest that endodontic sealers may participate of inflammation initiation due to chemical components released by them to periapical tissues.

IL-10 is a key anti-inflammatory cytokine that inhibits the production of pro-inflammatory cytokines such as IL-1 $\beta$, IL-6, and TNF- $\alpha$ (5). In our study, MTA Fillapex stimulated the release of IL-10 by hPDLSCs when compared with the control group and other sealers, which may have a positive local impact by attenuating an initial inflammatory response. Controversially, in a $3 \mathrm{D}$ in vitro root model experimental procedure, MTA Fillapex did not present the same effect (5). It is interesting to notice that, in the present study, none of the tested materials downregulated IL-10 production. Thus, it may be suggested that although the tested materials have induced inflammation at some extend, they did not affect the physiological production of IL-10, which is relevant to tissue repair.

Other cytokines, such as Interleukin-6 (IL-6), a pro-inflammatory cytokine that plays an important role in inflammatory reaction and bone resorption, was detected in the subcutaneous tissue of rats in contact with Bio-C Sealer (2). To the best of our knowledge, relevant information regarding TNF- $\alpha$ and IL-10 secretion by hPDLSCs stimulated with Bio-C Sealer and Cimmo HP® are missing in the literature.

Taken collectively, the results showed that PBS Cimmo HP ${ }^{\circledR}$, Bio-C Sealer and MTA Fillapex present mild and transient cytotoxicity (12) and slightly induce inflammatory mechanisms without compromising pro-reparative ones, which is of great interest for clinical practice. However, the results of the present in vitro study should not be extrapolated directly to clinical situations as it present limitations, which were previously addressed in literature (26). In addition, the application of in vitro results to clinical situations has been a great challenge (26). Thus, these results should be complemented by future in vitro studies and long-term clinical observations. 


\section{Acknowledgements}

The research was supported by grants and scholarships from São Paulo Research Foundation (FAPESP) (processes 2016/13944-5, 2017/23158-0 and 2018/13818-5), the National Council for Scientific and Technological Development (406923/2016-7) and Coordination for the Improvement of Higher Education Personnel (CAPES).

\section{Resumo}

Este estudo investigou o efeito de três materiais comerciais à base de silicato de cálcio (CSBM) na citotoxicidade e na produção de citocinas pró e antiinflamatórias em células-tronco do ligamento periodontal humano (hPDLSCs). Cultura de hPDLSCs foi estabelecida e caracterizada. Extratos de Bio-C Sealer (Angelus, Londrina, PR, Brasil), MTA Fillapex (Angelus, Londrina, PR, Brasil) e PBS Cimmo HP ${ }^{\circledR}$ (Cimmo Soluções em Saúde, Pouso Alegre, MG, Brasil) foram preparados com a colocação de espécimes dos cimentos $(5 \times 3 \mathrm{~mm})$ em meio de cultura. Em seguida, os extratos foram diluídos $(1,1: 2,1: 4,1: 8$, 1:16) e inseridos nos poços semeados de células para ensaio de citotoxicidade por meio de MTT por 24, 48 e $72 \mathrm{~h}$. As citocinas TNF- $\alpha$ e IL-10 foram quantificadas por ELISA em sobrenadantes de células de 24 h. Os dados foram analisados por ANOVA e teste de Tukey $(\alpha=0,05)$. Todos os CSBM exibiram alguma citotoxicidade que variou de acordo com a concentração do extrato e o tempo de avaliação. 0 MTA Fillapex apresentou os maiores efeitos citotóxicos com redução significativa da atividade metabólica / viabilidade celular quando comparado ao Bio-C Sealer e Cimmo HP ${ }^{\circledR}$. 0 TNF- $\alpha$ foi regulado positivamente pelos três cimentos testados $(p<0,05)$, enquanto apenas o MTA Fillapex regulou positivamente a liberação de IL-10 em comparação com o controle. Tomados em conjunto, os resultados mostraram que PBS Cimmo HP ${ }^{\circledR}$, Bio-C Sealer e MTA Fillapex apresentam citotoxicidade leve e transitória e induziram a produção de TNF- $\alpha$. O MTA Fillapex regulou positivamente a liberação de IL-10 por hPDLSCs. 


\section{References}

1. Donnermeyer D, Bürklein S, Dammaschke T, Schäfer E. Endodontic sealers based on calcium silicates: a systematic review. Odontology 2019;107:421-36.

2. Silva ECA, Tanomaru-Filho $M$, da Silva GF, Delfino MM, Cerri PS, Guerreiro-Tanomaru JM. Biocompatibility and Bioactive Potential of New Calcium Silicate-based Endodontic Sealers: Bio-C Sealer and Sealer Plus BC. J Endod 2020;46:1470-7.

3. Rodríguez-Lozano FJ, López-García S, García-Bernal D, Pecci-Lloret MR, Guerrero-Gironés J, Pecci-Lloret MP, et al. In vitro effect of putty calcium silicate materials on human periodontal ligament stem cells. Appl Sci 2020;10:3254.

4. Yoshino P, Nishiyama CK, Modena KCdS, Santos CF, Sipert CR. In vitro cytotoxicity of white MTA, MTA Fillapex ${ }^{\circledR}$ and Portland cement on human periodontal ligament fibroblasts. Braz Dent J 2013;24:111-6.5.

5. Gaudin A, Tolar M, Peters OA. Cytokine Production and Cytotoxicity of Calcium Silicate-based Sealers in 2- and 3-dimensional Cell Culture Models. J Endod 2020;46:818-26.

6. Okamura T, Chen L, Tsumano N, Ikeda C, Komasa S. Biocompatibility of a High-Plasticity, Calcium Silicate-Based, Ready-to-Use Material. Materials 2020;13:4770.

7. Zhou HM, Du TF, Shen Y, Wang ZJ, Zheng YF, Haapasalo M. In vitro cytotoxicity of calcium silicatecontaining endodontic sealers. J Endod 2015;41:56-61.

8. Oh H, Kim E, Lee S. Comparison of Biocompatibility of Calcium Silicate-Based Sealers and Epoxy Resin-Based Sealer on Human Periodontal Ligament Stem Cells. Materials 2020; 13:5242.

9. Shon WJ, Bae KS, Baek SH, Kum KY, Han AR, Lee W. Effects of calcium phosphate endodontic sealers on the behavior of human periodontal ligament fibroblasts and MG63 osteoblast-like cells. J Biomed Mater Res B 2012;100:2141-7.

10. Barbosa VM, Pitondo-Silva A, Oliveira-Silva M, Martorano AS, Rizzi-Maia CdC, Silva-Sousa YTC, et al. Antibacterial Activity of a New Ready-To-Use Calcium Silicate-Based Sealer. Braz Dent J. 2020;31:611-6.

11. Rovai ES, Ambrósio LMB, de França BN, de Oliveira LR, Gasparoni LM, Sipert CR. ProteaseActivated Receptor Type 1 Activation Enhances Osteogenic Activity in Human Periodontal Ligament Stem Cells. Stem Cells Int 2019;2019:6857386.12.

12. International Organization for Standardization ISO 10993-12 (E). Biological evaluation of medical devices - Part 5: Tests for in vitro cytotoxicity. Géneve: ISO; 2012.

13. López-García S, Pecci-Lloret MR, Guerrero-Gironés J, Pecci-Lloret MP, Lozano A, Llena C. Comparative Cytocompatibility and Mineralization Potential of Bio-C Sealer and TotalFill BC Sealer. Materials 2019;12:3087.

14. International Organization for Standardization 10993-5: 2009 Biological evaluation of medical devices-part 5: tests for in vitro cytotoxicity. Géneve: ISO; 1999.

15. Menicanin D, Mrozik KM, Wada N, Marino V, Shi S, Bartold PM, et al. Periodontal-ligamentderived stem cells exhibit the capacity for long-term survival, self-renewal, and regeneration of multiple tissue types in vivo. Stem Cells Dev 2014;23:1001-11.

16. Alvarez $\mathrm{R}$, Lee $\mathrm{HL}$, Wang $\mathrm{CY}$, Hong $\mathrm{C}$. Characterization of the osteogenic potential of mesenchymal stem cells from human periodontal ligament based on cell surface markers. Int J Oral Sci 2015;7:213-9.

17. Pintor AVB, Queiroz LD. MTT versus other cell viability assays to evaluate the biocompatibility of root canal filling materials: a systematic review. Int Endod J 2020;53:1348-73.

18. Zordan-Bronzel CL, Torres FFE, Tanomaru-Filho $M$, Chávez-Andrade GM, Bosso-Martelo $R$, Guerreiro-Tanomaru JM. Evaluation of physicochemical properties of a new calcium silicate-based sealer, Bio-C Sealer. J Endod 2019;45:1248-52.

19. Silva Neto JD, Schnaider TB, Gragnani A, Paiva APd, Novo NF, Ferreira LM. Portland cement with additives in the repair of furcation perforations in dogs. Acta Cir Bras 2012;27:809-14.

20. Zerbinatti CC, Veiga DF, Oliveira MAB, Mundim FGL, Pereira RM, Azevedo F, et al. Bioceramic cement in the filling of bone defects in rats. Acta Cir Bras 2019;34:e201900601.

21. Diomede F, Caputi S, Merciaro I, Frisone S, D'Arcangelo C, Piattelli A, et al. Pro-inflammatory cytokine release and cell growth inhibition in primary human oral cells after exposure to endodontic sealer. Int Endod J 2014;47:864-72.

22. Lee JK, Kim S. In Vitro Comparison of Biocompatibility of Calcium Silicate-Based Root Canal Sealers. Materials 2019;12:2411. 
23. Schutte RJ, Xie L, Klitzman B, Reichert WM. In vivo cytokine-associated responses to biomaterials. Biomaterials 2009;30:160-8.

24. Chang S-W, Lee S-Y, Kang S-K, Kum K-Y, Kim E-C. In vitro biocompatibility, inflammatory response, and osteogenic potential of 4 root canal sealers: Sealapex, Sankin apatite root sealer, MTA Fillapex, and iRoot SP root canal sealer. J Endod 2014;40:1642-8.

25. Lee BN, Hong JU, Kim SM, Jang JH, Chang HS, Hwang YC, et al. Anti-inflammatory and Osteogenic Effects of Calcium Silicate-based Root Canal Sealers. J Endod 2019;45:73-8.

26. de Souza Costa CA, Hebling J, Scheffel DLS, Soares DGS, Basso FG, Ribeiro APD. Methods to evaluate and strategies to improve the biocompatibility of dental materials and operative techniques. Dent Mater. 2014;30:769-84. 